\title{
REVIEW AND NEW DATA ON UPLIFT RATES AT THE W TERMINATION OF THE CORINTH RIFT AND THE NE RION GRABEN AREA (ACHAIA, NW PELOPONNESOS)
}

\section{Palyvos N. ${ }^{\left.1{ }^{*}\right)}$, Sorel D. ${ }^{2}$, Lemeille F. ${ }^{3}$, Mancini M. ${ }^{4}$, Pantosti D. ${ }^{1}$, Julia R. ${ }^{5}$, Triantaphyllou M. ${ }^{6}$, and De Martini P. M. ${ }^{1}$}

${ }^{1}$ Istituto Nazionale di Geofisica e Vulcanologia, Sez. Sismologia e Tettonofisica, Active Tectonics Group,palyvos@ingv.it,pantosti@ingv.it,demartini@ingv.it

${ }^{2}$ Université Paris-Sud, Centre d'Orsay, Faculty of Geology, 91405 Orsay Cedex, sorel@geol.upsud.fr

${ }^{3}$ Institut de Radioprotection et de Surete Nucléaire, Seismic Hazard Division, Fontenay-aux-roses Cedex,francis.lemeille@irsn.fr

${ }^{4}$ CNR - Istituto di Geologia Ambientale e Geoingegneria, Roma, marco.mancini@igag.cnr.it

${ }^{5}$ Institute of Earth Sciences Jaume Almera, Barcelona 08028, ramon.julia@ija.csic.es

${ }^{6}$ National and Kapodistrian University of Athens, Faculty of Geology and Geoenvironment, Department of Hist. Geology - Paleontology,mtriant@geol.uoa.gr

(*) now at Harokopio University, Geography Department, palyvos@hua.gr

\begin{abstract}
We review and present new geochronological data on the uplifted Middle-Late Pleistocene marine deposits at the western termination of the Corinth Rift and the Rion area. Geomorphological and geological observations define the general morphotectonic context of these deposits, which predicts a pattern of differential uplift. Uplift rate estimates based on previous geochronological data (ranging from 0.4 to $6 \mathrm{~mm} / \mathrm{yr}$ ) are discussed in the proposed morphotectonic context of differential uplift, together with estimates from new geochronological data. Based on the data available for post-MIS11 marine deposits, we conclude that time-averaged uplift rates in the last 300-200 ka have been higher than ca. $1.8 \mathrm{~mm} / \mathrm{yr}$ at the areas of faster uplift (e.g. Profitis Elias, Ano Kastritsi). To define just how higher than 1.8 $\mathrm{mm} / \mathrm{yr}$ they have been, and to cross-check the validity of very high uplift rate estimates $(\geq 4 \mathrm{~mm} / \mathrm{yr}$ ) existing in the bibliography, more datings than those available are required.
\end{abstract}

Key words: Tectonic geomorphology, differential coastal uplift, deformation rates, active normal faults, Corinth Gulf.

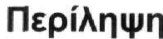

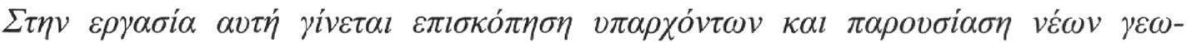

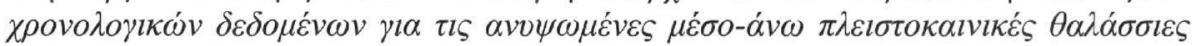

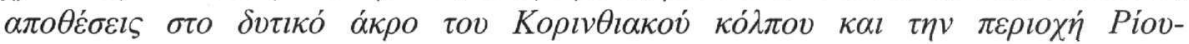

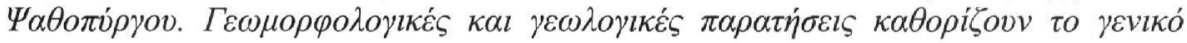




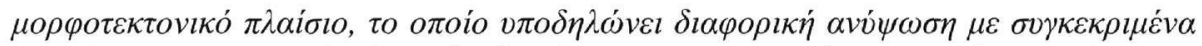

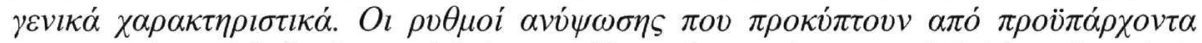

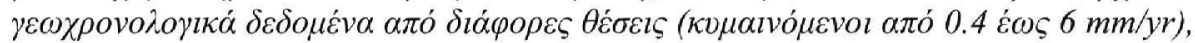

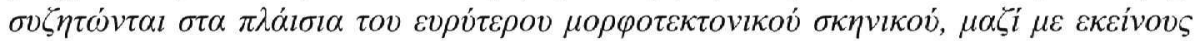

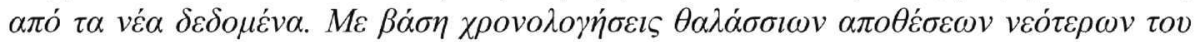

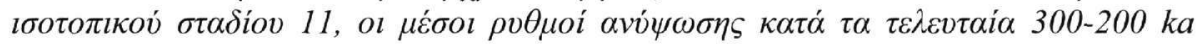

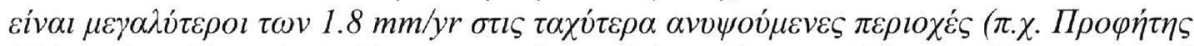

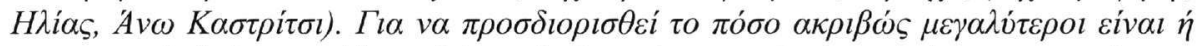

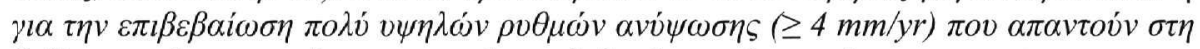

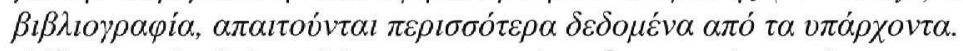

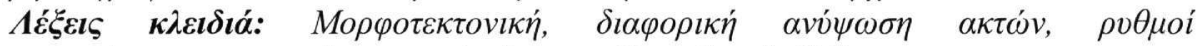

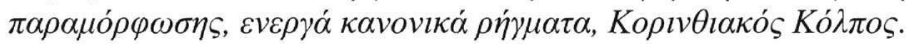

\section{Introduction}

The coast of NW Peloponnesos at the westernmost part of the Corinth Gulf Rift and the NE part of the Rion-Patras graben (inset in Fig. 1 top), is characterised by fast active uplift. Geochronological studies of uplifted Middle-Late Pleistocene marine deposits (Doutsos et al.1988, Frydas 1991, Doutsos and Poulimenos 1992, Stamatopoulos et al. 1994/2004, Frydas et al. 1995) have yielded average uplift rate estimates in the range 0.4 to $6 \mathrm{~mm} / \mathrm{yr}$ (Stamatopoulos et al. 1994, Kontopoulos and Zelilidis 1997, Houghton et al. 2003, Stamatopoulos et al. 2004) for the period since the Middle-Late Pleistocene, and 1.6-1.9 to $2.3 \mathrm{~mm} / \mathrm{yr}$ (minimum) for the Holocene (Palyvos et al. 2006 and subm. paper). In this communication, we review existing data on the geochronology of uplifted Pleistocene marine deposits. Subsequently, we discuss geomorphological and geological observations on the morphotectonic context of the uplifted marine deposits, and we present new Useries dating results / biostratigraphic data on the marine deposits. Afterwards, we discuss all uplift rate estimates the geochronological data translate to, in the frame of the identified morphotectonic context and the pattern of uplift it predicts.

Geomorphological and geological observations were carried out in the field, in aerial photographs of 1:15,000/1:30,000 scale and DEMs constructed from 1:5,000 and 1:50,000 HAGS maps. Useries dating was conducted with the total-sample dissolution method following the Bischoff and Fitzpatrick (1991) procedures, and the isotopic composition was determined by alpha spectroscopy. Samples of fine marine deposits were examined at SEM and Light microscope for calcareous nannoplankton content following standard procedures.

\section{Review of geochronological results and uplift rate estimates}

At the area of the westernmost part of the Corinth Rift and the NE part of the Rion-Patras graben, the lowest formation visible in the uplifted Pleistocene rift fill consists of coarse gravels of Early Pleistocene age (Symeonidis et al. 1987), about 200-600 m thick (Doutsos et al. 1988). These gravels were deposited in braider river environment and pass laterally to lacustrine/brackish deposits of the Rion-Antirion graben towards the SW (Kontopoulos and Zelilidis 1992, Frydas et al. 1995, Kontopoulos and Zelilidis 1997). Above the conglomerate formation, a formation of lacustrine, brackish and marine deposits is found at several locations and at different elevations (e.g. Frydas 1991, Doutsos and Poulimenos 1992, Frydas et al. 1995, Kontopoulos and Zelilidis 1997, Stamatopoulos et al. 2004).

Frydas (1991) studied diatom assemblages in lacustrine/brackish deposits at the area of Ano Zeria and specified equivalence to biozone MNN20 (270-440 ka, according to Gradstein et al. 2004), and an estimate of around 400ka for the age of the formation. Studies of nannoplankton assemblages by Frydas et al. (1995) in marine deposits in the broader area between Ano Kastritsi Patras (Fig. 1 top and farther W), recognised assemblages that suggest a biostratigraphic range from the upper (younger) part of biozone $\mathrm{CN} 14 \mathrm{~b}$ (equivalent to zone NN20, 440-270 ka) to the 
lower (older) part of biozone CN15 (equivalent to NN21, $270 \mathrm{ka}$ to present). Nannofossil analysis by Flotte et al. (2005) in marls at the Agios Ioannis (Ano Kastritsi) area, at $585 \mathrm{~m}$ above sea level -a.s.1.- (location in Fig. 1), identified nannofossils of biozone NN20, which includes the MIS 9 and 11 highstands (Fig. 2).

Radiometric datings (U-series) of marine macrofauna in the area of Figure 1 have been done by Stamatopoulos et al. (1994), Frydas et al. (1995, just W of Fig. 1), Houghton et al. (2003), Stamatopoulos et al. (2004). Stamatopoulos et al. (1994) dated corals found at $460 \mathrm{~m}$ a.s.l. SW of Ano Kastritsi and obtained an age of ca. $106 \mathrm{ka}$ (MIS 5c) and consequently, an average uplift rate (AUR) of ca. $4 \mathrm{~mm} / \mathrm{yr}$. Houghton et al. (2003) and Stamatopoulos et al. (2004) dated corals at the Drepanon area (Fig. 1), obtaining ages that allow correlation to a small sea-level highstand during MIS 6 and, AURs of $0.7-08$ and $0.4 \mathrm{~mm} / \mathrm{yr}$, respectively.

Apart from the corals near Drepanon, Stamatopoulos et al. (2004) also dated molluscs (Arca sp.) at Ano Kastritsi and Agios Georgios areas, at $615 \mathrm{~m}$ a.s.l. (Ag. Ioannis) and $451 \mathrm{~m}$ a.s.1. (Ag. Georgios), obtaining AURs if 2.8 and $4.8 \mathrm{~mm} / \mathrm{yr}$, respectively (locations in Fig. 1 - L. Stamatopoulos, pers. comm.). Whereas unrecrystallised (aragonitic) fossil coral is especially suitable for dating, molluscan shells are less suitable because their $U$ content is of mostly secondary origin, and because there is evidence for post-depositional $U$ loss $(\mathrm{Ku}, 2000$, Jedoui et al. 2003, and references therein) and provide "extremely unreliable ages" (quoting McLaren and Rowe 1996). According to McLaren and Rowe (1996), U-series ages from molluscs cannot in isolation (one dating, of one mollusc species) be demonstrated to be correct. Hillaire-Marcel et al. (1996) conclude that small differences between true and apparent ages (corresponding to early diagenesis) can be obtained in samples that were quickly cemented (cementation inhibiting further post-depositional U uptake), a condition that is frequently met in littoral environments. The Arca sp. dated in our study area did not come from cemented deposits though and, furthermore, in the study of Hillaire-Marcel et al. (1996), the mollusc that proved to be most problematic was in fact Arca, which showed much later diagenetic uptake of uranium (resulting in even younger apparent ages). Thus, the ages of the Arca shells may be minima only and the respective AUR estimates maxima. Whether the apparent ages may be slightly or substantially older than true ages, cannot be estimated.

\section{Morphotectonic context}

The geomorphic evolution of the study area has been controlled by the migration of fault activity from the basin-bounding faults (Kastritsti and Lakka f.z., Kfz and Lfz in Fig. 1) to parallel structures in the hangingwall of the latter. Namely, to the Rion-Patras, Psathopyrgos and AigionNeos Erineos fault zones (RPfz, Psfz and ANEfz in Fig. 1 - Doutsos et al. 1985/1988, Poulimenos and Doutsos 1992, Kontopoulos and Zelilidis 1997, Flotte 2003, Flotte et al. 2005, Palyvos et al. 2005 and references therein). The uplifted Middle-Late Pleistocene marine deposits in the area of interest are found at the parts of the Rion-Patras and Corinth basins that have been uplifting since the Middle-Late Pleistocene as a result of the aforementioned take-over by the presently active faults.

Maps of faults and/or the basin lithologies in the study area (all or parts of it) have been published by Doutsos et al. (1985, map of photolineations), Doutsos et al. (1988, lithostratigraphic map and map of faults from field mapping and photointerpretation), Doutsos and Poulimenos (1992, lithostratigraphic map and main fault zones only), Kontopoulos and Zelilidis (1997, lithostratigraphic map and map of faults), Koukouvelas and Doutsos (1997, map of faults) Stournaras et al. (1998, structural lineaments from remote-sensing), Stamatopoulos et al. (2004, revision of Kontopoulos and Zelilidis 1997), Flotte et al. (2003/2005, main structures only).

Our purpose being to try to understand the spatial variation of average uplift rates (the pattern of differential uplift) estimated at different locations in the study area, we focused a) on identifying those secondary faults at the footwall of the presently active coastal fault zones that are associated 
with geomorphic signatures and geological evidence suggesting activity after the deposition of Middle-Pleistocene marine deposits and, b) in discriminating between major and minor such secondary faults. The faults in the maps in Figure 1 have been drawn from the above view-point, and in the following, we briefly describe features that we consider more important in the morphotectonic setting. We note that several (or most) of the structures exist in the maps of the bibliography cited above, with smaller or larger differences, due to different map scale and different interpretation of observations. Figure 1 does not include faults not associated to substantial displacements in the later part of the Middle-Late Pleistocene (for such faults the reader is referred to maps in the bibliography).

Ano Rodini area. In the area of Figure 1 (top), the best-defined and largest secondary structure is the Ano Rodini fault zone (ARfz), at the footwall of the Psathopyrgos fault zone (partially mapped and shown in cross-section in Doutsos et al. 1988, also Stournaras et al. 1998). The ARfz trends ENE-WSW and it is located at the projection of the Ano Kastritsi f.z. to the NE The ARfz is not well-exposed in outcrops, but it has a distinct geomorphic expression for ca. $3 \mathrm{~km}$, an escarpment up to $220 \mathrm{~m}$ high, at the hangingwall of which brackish and marine deposits are preserved. The existence of the ARfz is also indicated by important contrasts in the bedding trends of the Early Pleistocene gravel formation across it (white stereoplots in Fig. 1), and the strong backtilt of marine deposits close to its trace (light gray stereoplot in Fig. 1). The latter backtilt is not characteristic of the broader area of the ARfz hangingwall. The overall morphology of the (intensely dissected) Ano Rodini plateau in front of the ARfz escarpment, is characterised by systematically decreasing elevations towards the NE, suggesting tilting (ca. $2^{\circ}$ ) towards the same direction (dashed line in Fig. 3 bottom). This NE-tilting is also suggested by bedding trends away from the ARfz (one example being the area to which the white stereoplot in Fig. 1 refers). We note that close to the Psathopyrgos escarpment, bedding trends in Early Pleistocene gravel formation deviate from the general NE trend identified in the morphology, due to effects of secondary faults see cross-section in Doutsos et al. 1988, where the bedrock occurrence along the Psfz escarpment is considered a horst, with faults also on the southern side (see also Koukouvelas and Doutsos 1997). We do not trace these faults in Fig. 1, because they are not associated with geomorphic signatures indicative of influence in the Middle-Late Pleistocene morphotectonic evolution of the area. The area where the marine deposits are preserved probably corresponds to a shallow graben, bound to the $\mathrm{N}$ by a fault secondary to the ARfz.

Zeria, Ano Zeria and Lambiri area. An important secondary structure belonging to the ANEfz is the NW-SE Ziria fault zone (Zfz - Fig. 1 bottom, included in the maps of Doutsos et al. 1988, and Stournaras 1998, with some differences). The Zfz corresponds to a dissected, but still very welldefined escarpment, which increases in height from the NW to the SE (up to around $200 \mathrm{~m}$; partial escarpment exhumation is also possible). The fault zone is generally not exposed in outcrops (for one exception, see Pantosti and Palyvos 2007), in which only minor faults sub-parallel to it can be seen or, small faults transverse or oblique to it. Apart from the conspicuous geomorphic discontinuity it corresponds to, the $\mathrm{Zfz}$ is also indicated by marked lithological contrast across it, along a significant part of its length. It juxtaposes the stratigraphically lower alluvial fan gravel formation (Kontopoulos and Zelilidis 1997) which occupies its footwall, against finer lacustrine, brackish and marine deposits (Doutsos et al. 1988, Frydas 1991, Doutsos and Poulimenos 1992), which are stratigraphically above the gravel (i.e. the $\mathrm{Zfz}$ displaces the lacustrine/marine formation). Faults belonging to the $\mathrm{Zfz}$ also cause abrupt transitions between the coarser lower part of the gravel formation and its finer upper part (in this area this distinction is possible). The contact between the gravel formation and the lacustrine/brackish/marine formation is a good stratigraphic marker, suggesting that the cumulative displacement hosted by the $\mathrm{Zfz}$ after the deposition of the lacustrine/marine formation is increasing towards the SE, in a scissor-like fashion, in accordance with the increasing height of the Ziria escarpment in the same direction. It is probable that the recently active Zfz is part of what was a larger structure in the past, a structure responsible for the abrupt down-stepping of the Pindos bedrock at the escarpment of the 

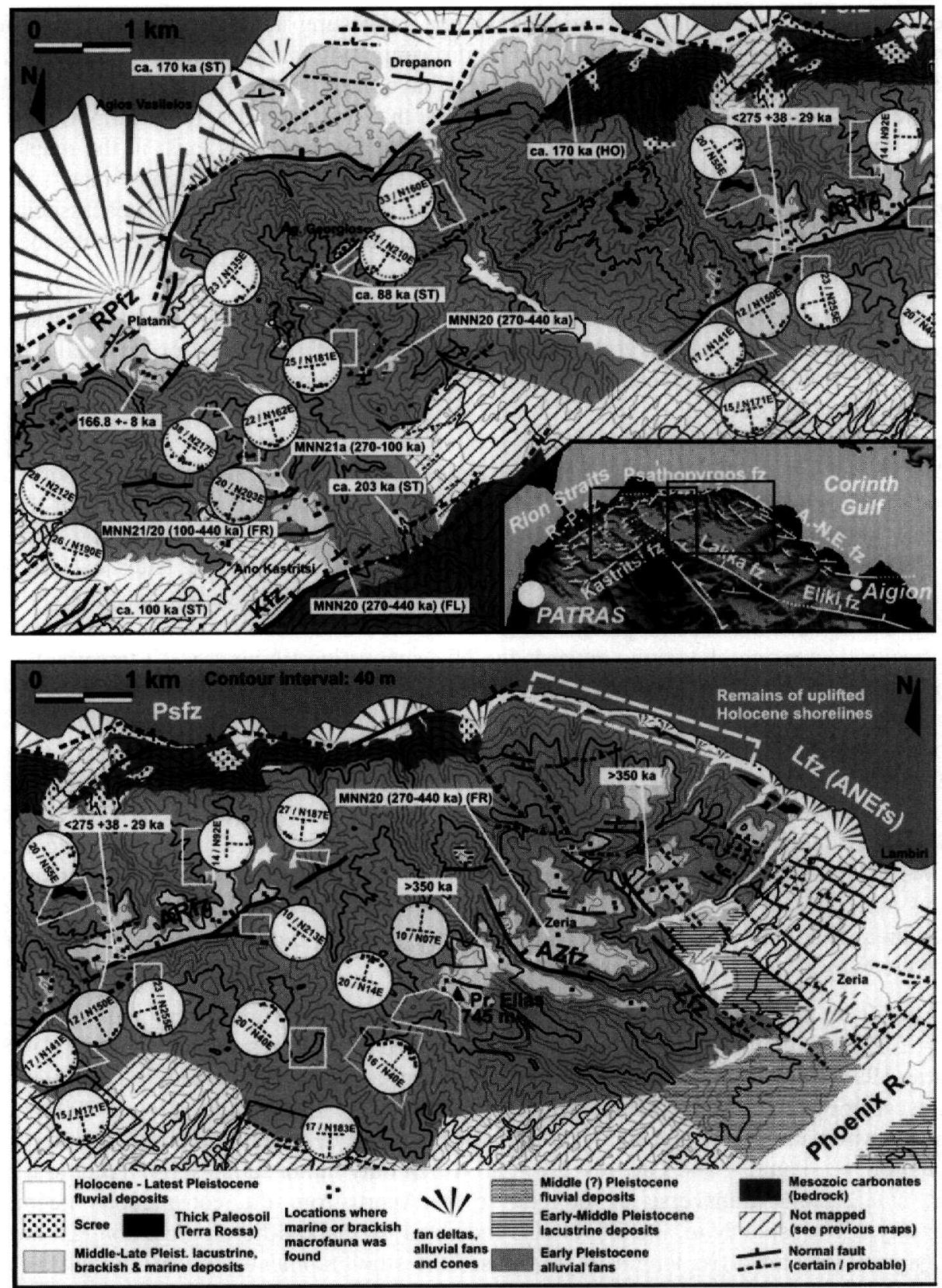

Figure 1 - Map of faults active in the last ca. $300 \mathrm{ka}$, based on geomorphological and geological observations in the field, DEMs and aerial photographs. Faults active in older periods are not depicted, the map is complementary to previously published maps by Doutsos et al. (1988), Doutsos and Poulimenos (1992), Kontopoulos and Zelilidis (1997) and Stamatopoulos et al. (2004), which include several (or most) of the fault traces, with differences due to different map scale and due to different interpretations. Line thicknesses are indicative of the amount of fault displacement. Lithological boundaries are from new field mapping (see also earlier maps with more or less small differences, in the works cited above). Stereoplots depict apparent dip measurements (in order to take advantage of measurements on inaccessible cliffs), the resultant true strike/dip estimates indicated by dashed lines 
Psathopyrgos fault zone at the exact projection of the Zfz trace in Figure 1, in the area where the Panagopoula landslide complex occurs (see also Pantosti and Palyvos 2007).

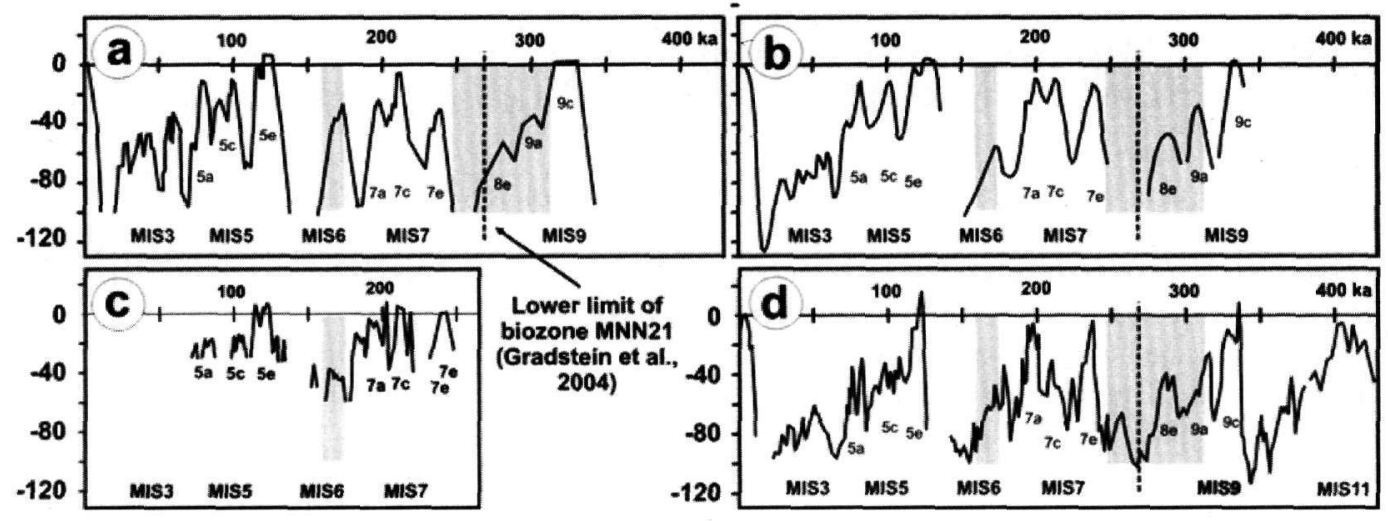

Figure 2 - Different Sealevel curves used in the estimation of average uplift rates. Grey rectangles indicate the age ranges obtained from new $\mathrm{U}$-series datings of coral samples. Sea level curves from: (a) Lajoie et al. (1991), (b) Chappell and Shackleton (1986) and Imbrie et al. (1984) for MIS 8 and 9, (c) Thompson and Goldstein (2005), (d) Siddall et al. (2003). The curves in (a) and (c) come from dated marine terraces in uplifting areas, whereas the other

two are based on oxygen isotope records in deep-sea cores

The second most important structure in the area is the Ano Zeria fz (AZfz in Fig. 1 bottom), to the SW of the Zfz, which is associated to an escarpment up to $120-140 \mathrm{~m}$ high and clear-cut downstepping of the formation with the marine deposits. In-between the $\mathrm{Zfz}$ and the coastal Lambiri f.z, a swarm of NW-SE-trending faults (included in the map and a cross-section in Doutsos et al. 1988, some also in Stournaras et al. 1998) is indicated by pristine geomorphic signatures, namely linear morphological discontinuities associated with scarps at valley divides and aligned tributary streams on the sides of the main valleys, abrupt lithological changes across them and, in some cases, they can also be observed in outcrops (see DEM from 1:5,000 maps and detailed map of faults in Pantosti and Palyvos 2007). The recognition of the smaller NW-SE faults permits us to avoid misinterpretation of the morphological steps in-between the Ziria and Lambiri fault escarpments, as remains of successive Pleistocene marine terraces. These NW-SE faults accommodate tilting to the SE and down to the NE stepping of the area between the Zfz and Lfz. The SE tilting is suggested by the overall morphology of the latter area (see Pantosti and Palyvos 2007), whereas down-stepping to the SE by NE-SW faults (as mapped by Doutsos et al. 1988) may also be superimposed on this general SE tilting trend.

Kastritsi - Agios Georgios area. Doutsos et al. (1988) identify a NE to ENE main structural trend in the broader Rio Graben. In the area of Figure 1 (top), the general trend of the main structures, the Kfz and the RPfz (e.g. Doutsos et al. 1985, Doutsos and Poulimenos 1992, Kontopoulos and Zelilidis (1997), Flotte et al. 2005) is NE-SW. As far as the pattern of secondary faults is concerned, Doutsos et al. (1988) mapped faults at various directions, Doutsos and Poulimenos (1992) measured faults with strikes varying from NE-SW to NW-SE (map of the measured faults not included), whereas Kontopoulos and Zelilidis (1997) report a fault pattern consisting of NE-SW normal faults and NW-SE transfer faults. The transfer faults are considered syn-sedimentary with respect to the Early Pleistocene alluvial fan formation, controlling the facies distribution within it (Kontopoulos and Zelilidis 1997). Stournaras et al. (1998) do not trace NWSE faults but several structural lineaments of E-W direction.

As previously specified, the faults in Figure 1 (top) are drawn from a viewpoint of impact on the morphotectonic evolution in the last ca. $300 \mathrm{ka}$. Thus, they do not include the NW-SE faults in Kontopoulos and Zelilidis (1997) and the prolongation of the Lakka fault zone along the Volinaios 
valley traced in Poulimenos and Doutsos (1992), also in order not to mix fault traces drawn with different degrees of generalization. The lengths of the fault traces in Figure 1, in several cases are expected to be underestimates of true fault lengths, due to fault signatures being lost or inconclusive in valleys by erosion and/or landsliding (intense in the area - see Rozos 1991). For the same reasons, we may have missed secondary faults with appreciable displacements in the last $300 \mathrm{ka}$.

Bibliographic data and our observations regarding the geometry of the RPfz are summarised in Palyvos et al. (2007, this volume). As far as secondary structures in-between the RPfz and the Kfz are concerned, in general terms, the available data suggest a pattern consisting of faults parallel to the general direction of the RPfz and Kfz, together with faults oblique to this direction. These faults are indicated by geological evidence and geomorphic discontinuities indicative of activity in the last $300 \mathrm{ka}$. The oblique faults have been simultaneously active with the NE-SW faults since they also displace the middle - Pleistocene marine deposits (Doutsos et al. 1988) and are associated with smaller or larger escarpments. Examples are the oblique faults (ENE-WSW and EW trending) at the Ano Kastritsi area and to its NW. Direct evidence of recent activity on transverse NW-SE fault zones we identified at the western divide of Volinaios, where in three cases such fault zones are associated to small graben, inside which downthrown marine deposits have escaped erosion.

Bedding in the area between the $\mathrm{Kfz}$ and the RPfz, in general dips $20-30^{\circ}$ towards the SW-SSW (Flotte et al. 2005); locally, steeper or gentler dips can be observed. Stereoplots in Figure 1 (top) include both Early Pleistocene gravel (white) and brackish/marine deposits above them (grey). The fact that both formations show comparably steep dips, indicates that the latter are the result of tilting (i.e. the strong dips of the alluvial fan gravel formation contain only a small component of depositional dip).

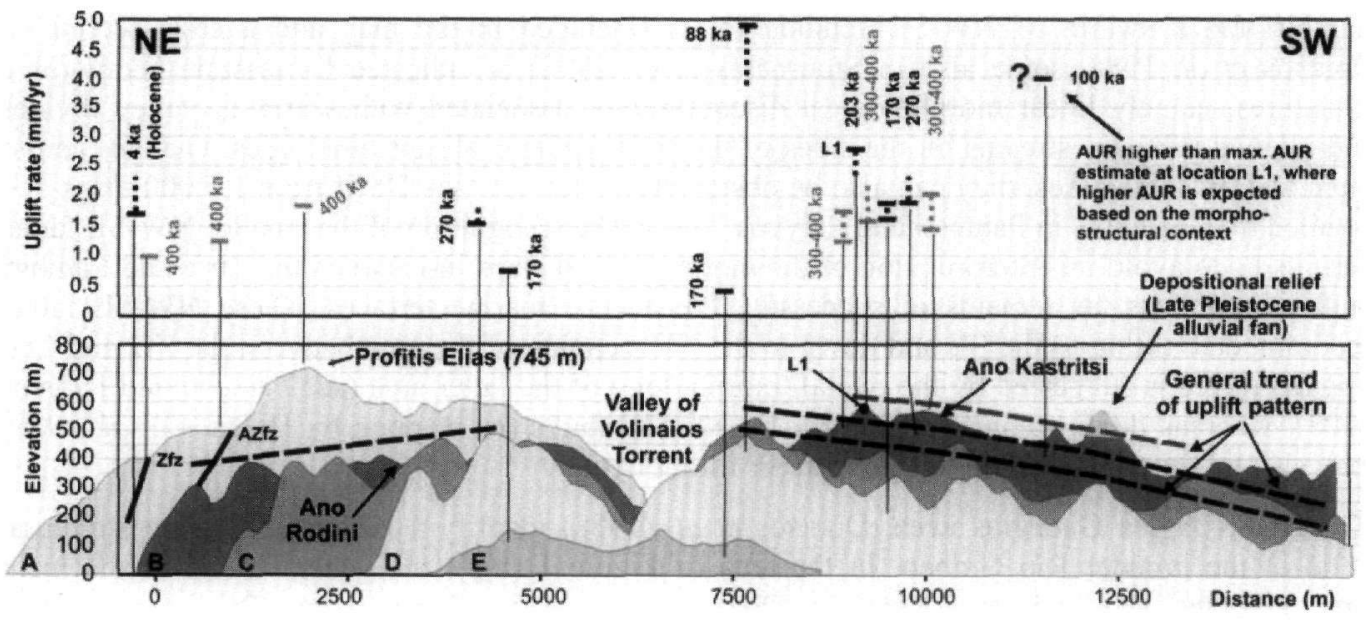

Figure 3 - Bottom: Topographic profiles along the study area (parallel to NE-SW main and secondary fault zones). Exact profile traces in Pantosti and Palyvos (2007). Thick dashed lines indicate the broad-scale pattern of uplift at the hangingwall of the Kastritsi and Ano Rodini fault zones (profiles B, C and D). Profile A is to the SE of the ARfz (passing from the Profitis Elias peak). Profile $\mathbf{E}$ crosses a small block at the intersection of the Rion- Patras and Psathopyrgos f.z., the fault zones active at present.

Top: Average uplift rate estimates since different periods of the Middle-Late Pleistocene, from previously available data (Frydas 1991, Frydas et al. 1995, Stamatopoulos et al. 1994, Houghton et al. 2003, Stamatopoulos et al. 2004) and new data from this study. Holocene uplift rate estimate from Palyvos et al. (2006) 
The area between the Kfz and the RPfz has been intensely dissected by fluvial erosion, yet, if the envelope of the relief is considered a "ramp" morphology is identified, with terrain elevations increasing from Patras towards the Volinaios Valley (Fig. 3 bottom). This morphology suggests ca. $2.3^{\circ}$ of broad-scale tilting towards the SW. An explanation for the discrepancy between the gentle broad-scale tilting suggested by geomorphology and the much steeper dips of Pleistocene strata (including the marine deposits of the last $300 \mathrm{ka}$ ), can be that the steep stratigraphic dips reflect local rotations of small blocks bounded by secondary faults in the area between the Kfz and the RPfz. This hypothesis, requires that transverse faults like those proposed by Kontopoulos and Zelilidis (1997), have had activity also after the deposition of the Early PLeistocene gravel formation.

\section{New geochronological data and uplift rate estimates}

Corals are indeed rare in most of the studied area and it was only after extensive search that we found some, in relatively few locations. An important point regarding the interpretation of the obtained U-series ages is their geomorphic and stratigraphic context. High rates of coastal uplift have resulted in intense erosion that has eradicated marine terraces in most of the area ("terraces" in a geomorphic sense), whereas ubiquitous faulting does not allow conclusive interpretation of knickpoints at the interfluves as evidence of paleoshorelines. Thus we do not have direct evidence that the sampled deposits are stratigraphically close to marine highstands.

Previous studies have identified that the deposits in the Corinth and Patras Gulfs basins have been alternating between lacustrine, brackish and marine conditions since the Middle Pleistocene (e.g. Keraudren and Sorel 1987, Frydas 1991, Piper et al. 1990 and references therein), due to the existence of sills on both the $\mathrm{W}$ and $\mathrm{E}$ extremities of the basins. In more recent periods (Late Pleistocene) an analogue is the isolation of the still-active parts of the basins by the Araxos and Rion Sills (e.g. Piper et al. 1990, Perissoratis et al. 2000 and references therein). In view of the above, the discussion in the following will be based on the assumption that the marine deposits should be close to peaks of the Middle-Late Pleistocene eustatic sea-level curve, i.e. we will exclude the lower sea-levels during glacial periods.

Profitis Elias-Ano Zeria area. We dated coral samples (Sorel et al. 2005) retrieved at 638 and $405 \mathrm{~m}$ a.s.l. from the first marine layer in the formation where Frydas (1991) found diatom assemblages biostratigraphically equivalent to biozone MNN20 (270-440 ka). We obtained ages older than the limit of the U-series method, i.e. "older than $350 \mathrm{ka}$ ". As already recognised by Doutsos et al. (1988), these deposits are downthrown to successively lower elevations by faults (see next section). Our datings verify the age estimate of "ca. 400 ka" by Frydas (1991) (MIS11 Fig. 2), in the sense that they exclude the MIS 9 (which is also within biozone MNN20). Assigning the deposits at the Profitis Elias peak (745 m) to the MIS11, we obtain an AUR estimate of ca. 1.8 mm.yr and successively lower ones at down-faulted occurrences of the formation (Fig. 3 top).

Ano Rodini area. At the area of Ano Rodini, we found relatively abundant Cladocora sp. corals at three neighbouring locations. A coral sample at $\sim 440 \mathrm{~m}$ a.s.l. was dated with the U-series method and gave an age of $275.05+38.4 /-28.8 \mathrm{ka}$. The ${ }^{230} \mathrm{Th} /{ }^{232} \mathrm{Th}$ ratio for this sample was below 20 (highlighted in gray in Table 1), indicating contamination with detrital Th. Such contamination results in apparent ages that are older than the true age of a sample. Thus, the obtained age is a maximum-limiting age. Considering that the marine deposits containing the corals most likely should correspond to a period of high sea-level (due to the sill existing farther west), based on the obtained oldest possible age $(275+38.4=313.4 \mathrm{ka})$, the dated corals should not be older than the MIS 9a highstand (Fig. 2). Assigning them to MIS 9a we obtain a minimum AUR in the range $1.49-1.57 \mathrm{~mm} / \mathrm{yr}$. Given that the limit between biozones MNN20 and MNN21a (ca. $270 \mathrm{ka}$ ) is close to the obtained age, it would provide a useful constraint on the true age of the deposits from which the corals came from. We carried out nannofossil analyses on two samples of fine nearshore 
deposits at 2 different outcrops but, unfortunately both samples were devoid of calcareous nannofossil assemblages.

Ano Kastritsi and Agios Georgios areas. We dated a coral (Cladocora sp.) sample retrieved at $252 \mathrm{~m}$ a.s.1., obtaining an age of $166.82+7.7 /-7.2 \mathrm{ka}$ (Fig. 1, Table 1). Micropaleontological analyses identified biozone MNN21a at $480 \mathrm{~m}$ a.s.l. (Ano Kastritsi interfluve) whereas a third sample was found to belong to biozone MNN20 (at ca. $492 \mathrm{~m}$ a.s.l., Agios Georgios interfluve).

Table 1 - Results of U-series dating of corals from Pleistocene marine deposits. Gray highlight indicates sample slightly contaminated by detrital $\mathrm{Th}$ (provides maximum age only)

\begin{tabular}{|c|c|c|c|c|c|c|c|}
\hline Sample & $\begin{array}{c}\text { Eleva- } \\
\text { tion a.s.l. } \\
\text { (m) }\end{array}$ & $\begin{array}{c}{ }^{238} \mathbf{U} \\
(\mathbf{p p m})\end{array}$ & $\begin{array}{c}{ }^{232} \mathbf{T h} \\
\mathbf{( p p m )}\end{array}$ & ${ }^{{ }^{230} \mathbf{T h} /{ }^{\mathbf{2 3 2}} \mathbf{T h}}$ & $\begin{array}{c}{ }^{230} \mathbf{T h} / \\
{ }^{234} \mathbf{U}\end{array}$ & $\begin{array}{c}{ }^{234} \mathbf{U} / \\
{ }^{238} \mathbf{U}\end{array}$ & $\begin{array}{c}\text { Age } \\
\text { (ka) }\end{array}$ \\
\hline $\begin{array}{c}\text { Profitis Elias } \\
(1103)\end{array}$ & 638 & 1.88 & 0.23 & $31.863 \pm 1.194$ & $\begin{array}{c}1.14 \\
\pm 0.03\end{array}$ & $\begin{array}{c}1.10 \\
\pm 0.01\end{array}$ & $\geq \mathbf{3 5 0}$ \\
\hline $\begin{array}{c}\text { Ano Zeria } \\
(1003)\end{array}$ & 405 & 1.58 & 0.31 & $20.762 \pm 0.568$ & $\begin{array}{c}1.17 \\
\pm 0.03\end{array}$ & $\begin{array}{c}1.11 \\
\pm 0.01\end{array}$ & $\geq \mathbf{3 5 0}$ \\
\hline $\begin{array}{c}\text { Ano Rodini } \\
\text { TS (506) }\end{array}$ & 436 & 2.63 & 0.80 & $10.922 \pm 0.363$ & $\begin{array}{c}0.95 \\
\pm 0.03\end{array}$ & $\begin{array}{c}1.13 \\
\pm 0.02\end{array}$ & $\begin{array}{c}\mathbf{2 7 5 . 0 5} \\
+38 /-29\end{array}$ \\
\hline $\begin{array}{c}\text { Platani } \\
\text { TS (3406) }\end{array}$ & 252 & 2.1 & 0.15 & $34.969 \pm 1.523$ & $\begin{array}{c}0.79 \\
\pm 0.01\end{array}$ & $\begin{array}{c}1.01 \\
\pm 0.01\end{array}$ & $\begin{array}{c}\mathbf{1 6 6 . 8 2} \\
+7.7 /-7.2\end{array}$ \\
\hline
\end{tabular}

The only highstand included in the age range obtained for the corals at $252 \mathrm{~m}$, is the MIS6e highstand (Fig. 2). The MIS6e highstand, depending on which eustatic curve is followed, may consist of one or two (shorter-lived) highstands. Using different curves in Figure 2 we obtain AUR estimates in the range $1.61-1.80 \mathrm{~mm} / \mathrm{yr}$. We note that if the younger ages in the obtained age range are considered, uplift rate estimates would be higher (also because paleo-sealevel was lower).

The identification of biozone MNN21a provides a maximum-limiting age for the relevant deposits, thus it can be used to estimate minimum values for AUR. The base of MNN21a is placed at around $270 \mathrm{ka}$ (Gradstein et al. 2004). If these limits are taken literally, the oldest highstands allowed for would be in MIS 7 (7e), translating to min. AUR in the range 1.99-2.14 mm/yr for the deposits at $480 \mathrm{~m}$ a.s.l. (using different curves in Fig. 2). Based on U-series datings and correlation of marine terrace remains at the broader area of Aravonitsa farther E (Pantosti and Palyvos 2007, and paper in prep.), deposits that were found to be marginally within zone MNN21a correlate most probably to the MIS 8e highstand, which is just out of the lower limit of MNN21. Given that the latter limit is not exact (it is associated to an error of several ka) and that works putting it to $285 \mathrm{ka}$ do exist, in order to be on the safe side, we will estimate a minimum AUR assuming that the marine deposits at $480 \mathrm{~m}$ correlate to the highstand at MIS8e or younger highstands. This way, we obtain a min. AUR in the range $1.79-1.89 \mathrm{~mm} / \mathrm{yr}$.

The presence of MNN20 at $492 \mathrm{~m}$ a.s.l. (within a small graben) translates to a min. AUR of 1.23 $\mathrm{mm} / \mathrm{yr}$ (assigning the deposits to the oldest highstand in MNN20, i.e. the MIS11 at ca. $400 \mathrm{ka}$ ) and max. AUR of 1.64-1.78 mm/yr, if assigned to the youngest possible highstand in MNN20 (MIS9a). The MNN20 deposits at the location sampled by Flotte et al. (2005) at $585 \mathrm{~m}$ a.s.l., translate to a min. $1.46 \mathrm{~mm} / \mathrm{yr}$ and $\max .1 .94-2.08 \mathrm{~mm} / \mathrm{yr}$ AUR with the same reasoning as above (Fig. 3 top). The highest remains of marine deposits in the same area are at about $620 \mathrm{~m}$ a.s.l., where Stamatopoulos et al. 2004 obtained an age of $203 \mathrm{ka}$ from molluscs (an age that we consider as minimum-limiting, and the respective AUR of $2.8 \mathrm{~mm} / \mathrm{yr}$ as maximum-limiting). Based on the fact that the oldest purely marine deposits above the Early Pleistocene alluvial fan formation belong to MIS 11 (Frydas 1991 and also the U-series datings herein), these deposits cannot be older than MIS11. Assigning them to MIS11, translates to $1.55 \mathrm{~mm} / \mathrm{yr}$ minimum AUR (Fig. 3 top). 


\section{Discussion and conclusions}

The obtained average uplift rates (AURs) at different locations (the AUR "field"), should be viewed and interpreted in the context of the identified broad-scale morphotectonic pattern, the changes of rates of activity of the involved main fault systems in the period of interest (i.e. the timing of decrease of activity or death of the $\mathrm{Kfz}$ ), and in more detail, the pattern of secondary faults and the movements of the smaller fault blocks they define, that are superimposed on this broad-scale deformation. The simplest example of the significance of the above in the study area, concerns the AURs at the Drepanon (Houghton et al. 2003, Stamatopoulos et al. 2004), which refer to small blocks at the intersection of the Psfz and the RPfz, and not to "the western end of the Gulf of Corinth" (Houghton et al. 2003).

The highest remains of marine deposits are found at Profitis Elias (PE) in a formation that dates to the MIS11 (Frydas 1991 and this study) and indicates an AUR of ca. $1.8 \mathrm{~mm} / \mathrm{yr}$. They correspond to the first marine incursion in the Corinth Rift during the Middle Pleistocene (as recognised also at the E part of the Rift, by Keraudren and Sorel 1987). The min. AUR at Ano Rodini (1.49-1.57 $\mathrm{mm} / \mathrm{yr}$ ) indicates that at the hangingwall of the ARfz, where we would expect a substantially smaller AUR compared to PE (because the dated marine deposits have been downthrown by the ARfz), we get a comparable min. AUR instead. Also the minimum estimates of Holocene uplift rate in the same area (1.6-2.3 mm/yr Palyvos et al. 2006 and paper in prep.) are comparable to the min. AUR at PE. The interpretation we propose is that the AUR at PE, because it is derived from the oldest marine deposits (MIS11), it includes a component of subsidence from the Lakka f.z. (Lkfz), at the hangingwall of which it was deposited. The above is supported by the fact that the dated deposits at PE are not associated to a marine terrace, but a marine intercalation within lacustrine deposits (Frydas 1991, see also Pantosti and Palyvos 2007). Terraces would start forming only after the uplift from the presently active coastal faults superseded the subsidence by the Lfz (causing net uplift above present sea level), due to decrease in the activity or, complete death of the latter. Erosion may have removed a post-MIS11 terrace above them (see Pantosti and Palyvos 2007 for locations of probable post-MIS11 marine deposits in the broader PE area, remnants of younger sequences eroded away).

Given the above, the usual assumption that uplift rate may considered constant through the Middle-Late Pleistocene, is not applicable in our case. Thus, AUR estimates from MIS11 deposits cannot be compared with the AURs from younger deposits, which are expected to be higher (at the same locations, that is). This is observed at Ano Kastritsi, where the AUR from the MNN20 deposits at $585 \mathrm{~m}$ a.s.1. (1.46-2.08 mm/yr) is comparable or smaller to AURs estimated from younger marine deposits that have been down thrown substantially by secondary faults (Platani corals and MNN21 at $480 \mathrm{~m}$ a.s.l., yielding 1.6-1.8 and min. 1.79-1.89 mm/yr AUR). The uplift rates from post MIS11 deposits at these latter locations is, imply even higher post-MIS11 AURs at the footwalls of the relevant secondary faults (and consequently, also at the areas of the highest occurrences of marine deposits at 585 and $620 \mathrm{~m}$ ).

Based on a conservative reading of the available data from post-MIS11 marine deposits, we conclude that AURs in the last 300-200 ka have been higher than $1.7-1.8 \mathrm{~mm} / \mathrm{yr}$ at the faster uplifting areas (Profitis Elias, Ano Kastritsi). For comparison, based on three U-series datings along a transect just to the SE of Figure 1 (bottom), in the Aravonitsa-Selianitika area, AURs in the last 300-200 ka have been of the order of 1.5-1.6 mm/yr or somewhat higher (Pantosti and Palyvos 2007 and paper in prep.). In the area studied herein, defining just how higher than 1.8 $\mathrm{mm} / \mathrm{yr}$ AURs have been, requires more data than those available. E.g. the $4 \mathrm{~mm} / \mathrm{yr}$ AUR obtained by Stamatopoulos et al. (1994) to the SW of Ano Kastritsi, given the general pattern of differential uplift that predicts increasing AUR towards Ano Kastritsi, it implies even higher AUR at the latter area (Kontopoulos and Zelilidis 1997 estimated $6 \mathrm{~mm} / \mathrm{yr}$ ). Values of 4 and $6 \mathrm{~mm} / \mathrm{yr}$ being indeed very high and, implying even higher AUR at Profitis Elias, together with a contradiction with the 
$\max$ AUR of. $2.8 \mathrm{~mm} / \mathrm{yr}$ obtained at $620 \mathrm{~m} \mathrm{NE}$ of Kastritsi by Stamatopoulos et al. (2004), indicate that more dating of corals at the same and other locations is more than desirable.

Should a more or less well-defined staircase of marine terraces unaffected by faulting had been present, the available data would have been more than enough to constrain the uplift rate at the area of interest, to identify erroneous datings, and to determine the timing of the switch of activity from the Kfz to the Rpfz. The contrary being the case (no terraces, a lot of faults, lack of corals at critical locations), the riddle remains to be resolved by further studies.

\section{Acknowledgments}

This work was conducted in the frame of the 3HAZ Corinth EU project, and CNRS project GDR Corinthe n. 234. We warmly thank Leonidas Stamatopoulos (University of Patras) for discussion, for giving us details on locations of marine samples dated with the U-series and for pointing out and providing us previous works. We appreciate the constructive review of the submitted manuscript by Gerald Roberts (Birkbeck College - University of London), whom we also thank.

\section{References}

Bischoff, J.L., Fitzpatrick, J.A., 1991. U-series dating of impure carbonates: an isochron technique using total-sample dissolution, Geochimica et Cosmochimica Acta, 55, 543-554.

Chappell, J., and Shackleton, N.J., 1986. Oxygen isotopes and sea-level, Nature, 324, 137-140.

Doutsos, T., Kontopoulos, N., and Ferentinos, G., 1985. Das westliche ende des Korinth-Grabens, N. Jb. Geol. Palaont. Mh., H11, 652-666.

Doutsos, T., Kontopoulos, N., and Poulimenos, G., 1988, The Corinth-Patras Rift as the initial stage of continental fragmentation behind an active island arc (Greece), Basin Research, 1, 177-190.

Doutsos, T., and Poulimenos, G., 1992. Geometry and kinematics of active faults and their seismotectonic significance in the western Corinth-Patras rift (Greece), Journal of Structural Geology, 14 (6), 689-699.

Flotté, N. 2003. Caracterisation structurale et cinematique d'un rift sur detachement: Le rift de Corinthe-Patras, Grece, These doct., 196pp., Univ. de Paris-Sud.

Flotte, N., Sorel, D., Muller, C., and Tensi, J., 2005. Along strike changes in the structural evolution over a brittle detachment faultç example of the Pleistocene Corinth-Patras Rift (Greece), Tectonophysics, 403, 77-94.

Frydas, D., 1991. Palaookologische und stratigraphische untersuchugen der diatomeen des pleistozans der N. Peloponnes, Griechenland, Bull. Geol. Soc. Greece, XXV/2, 499-513.

Frydas, D., Kontopoulos, N., Stamatopoulos, L., Guernet, C., and Voltaggio, M., 1995. MiddleLate Pleistocene sediments in the northwestern Peloponnesus, Greece. A combined study of biostratigraphical, radiochronological and sedimentological results, Berliner Gowiss, E16, 589-605.

Hillaire-Marcel,C., Gariepy, C., Ghaleb, B., Goy, J.-L., Zazo, C., and Barcelos, J.C., 1996. USeries measurements in Thyrrhenian deposits from Mallorca - further evidence for two last-interglacial high sea levels in the Balearic Islands, Quaternary Science Reviews, 15, 53-62.

Houghton, S.L., Roberts, G.P., Papanikolaou, I.D., and McArthur, J.M., 2003. New 234U-230 ${ }^{\text {Th }}$ coral dates from the western Gulf of Corinth: implications for extensional tectonics, Geophysical Research Letters, 30(19), 2013. doi:10.1029/2003GL018112 
Jedoui, Y., Reyss, J.-L., Kallel, N., Montacer, M., and Davaud, E., 2003, U-series evidence for two high Last Interglacial sea levels in southeastern Tunisia, Quat. Sci. Rev., 22, 343-351.

Keraudren, B., and Sorel, D., 1987. The terraces of Corinth (Greece) - A detailed record of eustatic sea-level variations during the last 500,000 years, Marine Geology, 77, 99-107.

Kontopoulos, N., and Zelilidis, A., 1992. Upper Pliocene lacustrine environments in the intramontane Rio graben basin, NW Peloponnesus, Greece, N. Jb. Geol. Palaont. Mh., H2, 102-114.

Kontopoulos, N., and Zelilidis, A., 1997. Depositional environments of the coarse-grained lower Pleistocene deposits in the Rio-Antirio basin, Greece. In G. Marinos, et al. (eds), Engineering Geology and the Environment, A. A. Balkema, Rotterdam, 199-204.

Koukouvelas, I., and Doutsos, T., 1997. The effects of active faults on the generation of landslides in NW Peloponnese. In G. Marinos, et al. (eds), Engineering Geology and the Environment, A. A. Balkema, Rotterdam, 799-804.

$\mathrm{Ku}$, T.-L., 2000. Uranium series methods, In Noller et al. (eds), Quaternary Geochronology methods and applications, AGU reference shelf 4, 101-114.

Lajoie, K.R., Ponti, D.J., Powell, C.L., Mathieson, S.A., and Sarna-Wojcicki, A.M., 1991. Emergent marine strandlines and associated sediments, coastal California: a record of Quaternary sea-level fluctuations, vertical tectonic movements, climatic changes and coastal processes, In R.B. Morrison (ed.), Quaternary Non-Glacial Geology: Conterminous United States: Geological Society of America Decade of North America Geology, K-2, 190-214pp.

McLaren, S.J., and Rowe, P.J., 1996. The reliability of Uranium-series mollusc dates from the western Mediterranean basin, Quaternary Science Reviews, 15, 709-717.

Palyvos, N., Pantosti, D., Stamatopoulos, L., and De Martini, P.M., 2007a. A geomorphological reconnaissance of the Psathopyrgos and Rion-Patras fault systems (Achaia, NW Peloponnesus), Bull. Geol. Soc. Gr., XXXVII. (submitted)

Palyvos, N., Lemeille, F., Sorel, D., Pantosti, D., Pavlopoulos, K., and Philippon, J., 2006. Undocumented uplifted Holocene shorelines at the western termination of the Corinth Gulf Rift: a record of coseismic uplift episodes? Geophysical Research Abstracts, vol. 8, 04754.

Palyvos, N., Pantosti, D., DeMartini, P. M., Lemeille, F., Sorel, D., and Pavlopoulos, K, 2005. The Aigion-Neos Erineos normal fault system (Western Corinth Gulf Rift, Greece): Geomorphological signature, recent earthquake history and evolution, Journal of Geophysical Research, Vol. 110, No. B9, B09302, 15 pp.

Pantosti, D., and Palyvos, N., (eds), 2007. "3HAZ Corinth" Project Deliverable 30, Maps of active faults, marine terraces and landslides, Unpubl. Report, INGV.

Perissoratis, C., Piper, D.J.W., and Lykousis, V., 2000. Alternating marine and lacustrine sedimentation during the late Quaternary in the Gulf of Corinth rift basin, central Greece, Marine Geology, 167, 391-411.

Piper, D.J.W., Doutsos, T., and Stamatopoulos, L., 1990. Quaternary history of the Gulfs of Patras and Corinth, Greece, Z. Geomorphol., 34, 4, 451-461.

Rozos, D., 1991. Engineering geological conditions in Achaia Province - geomechanical characteristics of the Plio-Pleistocene Sediments, PhD Thesis, Department of Geology, University of Patras. (in Greek) 
Siddall, M., Rohling, E.J., Almogi-Labin, A., Hemleben, C., Meischner, D., Schmelzer, I., and Smeed, D.A., 2003, Sea-level fluctuations during the last glacial cycle, Nature, 423, 853858.

Sorel, D., Pantosti, D., Lemeille, F., Palyvos, N., and De-Martini, P.M., 2005, The step-over between the Eliki and Aigion fault systems: slip transfer and present rates of activity. Unpubl. report for CNRS project GDR Corinthe $\mathrm{n}^{\circ} 234,13 \mathrm{pp}$.

Stamatopoulos, L., Voltaggio, M., and Kontopoulos, N., 1994. ${ }^{230} \mathrm{Th} /{ }^{238} \mathrm{U}$ dating of corals from Tyrrhenian marine deposits and the Palaeogeographic evolution of the Western Peloponnesus (Greece), Munster. Forsch. Geol. Palaont., 76, 345-352.

Stamatopoulos, L., Kontopoulos, N., Voltaggio, M., and Branca, M., 2004. Radiochronological data with U/Th method in lagoonal/marine deposits of the NW Peloponnese, Greece. Bull. Geol. Soc. Greece, XXXVI, 1064-1067. (in Greek)

Stournaras, G., Tsimpidis, G., Tsoumanis, P., Yannatos, G., and Guillande, 1998. Instability phenomena in the Neogene deposits of Northern Peloponnesus, Greece, Bull. Eng. Geol. Env., 57, 65-68.

Symeonidis, N., Theodorou, G., Schutt, H., and Velitzelos, E., 1987. Paleontological and stratigraphical observations in the area of Achaia and Etoloakarnania (W Greece), Ann. Geol. Pays. Hellen., 38, 317-353.

Thompson, W.G., and Goldstein, S.L., 2005. Open-system coral ages reveal persistent suborbital sea-level cycles, Science, 308, 401-404.

Tsoflias, P., and Loftus, D.L., 1971. Geological map of Greece in 1:50,000- Nafpaktos sheet, IGME, Athens. 